\title{
Karakteristik Perubahan Penggunaan Lahan yang Tidak Sesuai Rencana Tata Ruang Di Koridor Lingkar Timur Sidoarjo
}

\author{
Kathon Wira Ajimas dan Putu Gde Ariastita \\ Jurusan Perencanaan Wilayah dan Kota, Fakultas Teknik Sipil dan Perencanaan, \\ Institut Teknologi Sepuluh Nopember (ITS) \\ Jl. Arief Rahman Hakim, Surabaya 60111 Indonesia \\ e-mail: ariastita@gmail.com
}

\begin{abstract}
Abstrak-Untuk mempermudah akses, memecah kemacetan, serta pembangunan wilayah, Pemerintah Daerah Kabupaten Sidoarjo membangun Jalan Lingkar Timur Sidoarjo pada tahun 2006. Pembangunan jalan Lingkar Timur Sidoarjo dapat meningkatkan nilai lokasi dari lahan di sekitar koridor jalan tersebut karena adanya peningkatan aksesibilitas yang ada. Peningkatan nilai lokasi ini kemudian menyebabkan perubahan penggunaan lahan yang tidak sesuai rencana. Karakteristik perubahan penggunaan lahan di perlukan untuk menangani perubahan lahan di koridor Lingkar Timur Sidoarjo . Penelitian ini bertujuan untuk mengidentifikasi karakteristik perubahan penggunaan lahan yang tidak sesuai rencana tata ruang di koridor Lingkar Timur Sidoarjo. Untuk mencapai tujuan tersebut dilakukan dengan cara mengidentifikasi karakteristik perubahan penggunaan lahan berdasarkan jenis-jenis perubahan lahan, luas lahan, dan kecepatan perubahan lahan dengan menggunakan analisis deskriptif yaitu segmentasi wilayah. Berdasarkan hasil yang ditemukan pada segmen satu, perubahan lahan pertanian menjadi permuikiman adalah $1,3 \mathrm{ha} /$ th (lambat), Permukiman menjadi pergudangan adalah 0,7 ha/th (lambat), dan pertanian menjadi pergudangan adalah 5,9 ha/th (cepat. Perubahan ). Perubahan lahan yang terjadi pada segmen 2, perubahan lahan pertanian menjadi permukiman adalah 4,4 ha/th sedang dan pertanian menjadi fasilitas umum $6,3 \mathrm{ha} / \mathrm{th}$ (cepat).
\end{abstract}

Kata Kunci-Perubahan penggunaan lahan

\section{PENDAHULUAN}

$\mathrm{A}$ LIH fungsi lahan dalam arti perubahan penggunaan lahan, pada dasarnya tidak dapat dihindarkan dalam pelaksanaan pembangunan (Lisdiyono, 2004). Pertumbuhan penduduk yang pesat serta bertambahnya tuntutan kebutuhan masyarakat akan lahan, seringkali mengakibatkan benturan kepentingan atas penggunaan lahan serta terjadinya ketidaksesuaian antara penggunaan lahan dengan rencana peruntukannya (Khadiyanto, 2005) [1]. Sedangkan lahan itu sendiri bersifat terbatas dan tidak bisa ditambah kecuali dengan kegiatan reklamasi (Sujarto, 1985). Keterbatasan lahan di perkotaan juga menyebabkan kota berkembang secara fisik ke arah pinggiran kota[2].

Adapun bentuk pengelolaan tanah yang dilakukan pemerintah meliputi perencanaan, jaringan infrastruktur, dan fungsi pengaturan untuk tujuan melakukan perluasan kota dalam memberikan kerangka fisik dan hukum setiap proyek pembangunan yang dilakukan oleh pihak swasta maupun masyarakat (Nurmandi, 2014: 145). Haryadi (1992) menyatakan bahwa perubahan lahan terutama yang terjadi di wilayah perkotaan disebabkan adanya pembangunan jalan kolektor primer dalam skalabesar di wilayah pinggiran kota dimana pembangunannya akan mengkonsumsi lahan di wilayah tersebut dan akan terjadi pembangunan [3].

Pembangunan jalan yang tepat, tentunya akan memberikan dampak yang positif apabila dikelola dengan baik, akan tetapi pembangunan yang berjalan seringkali terkendala terhadap ketersediaan lahan khususnya lahan perkotaan. Pendekatan kawasan berorientasi pada pencapaian atau terwujudnya fungsi tertentu dari suatu kawasan, sedangkan pendekatan tata ruang mengarah pada penentuan lokasi pembangunan yang tepat. Kedua pendekatan tersebut mengarah kepada pencapaian efektivitas dan efisiensi pembangunan (Yunus, 1999). Karena kondisi dan potensi masing-masing wilayah bervariasi satu sama lainnya, maka pendekatan kawasan dan pendekatan tata ruang yang diterapkan di masing-masing wilayah menjadi berbeda-beda, namun tidak menutup kemungkinan diantara beberapa wilayah dapat diterapkan pendekatan yang sama. Pada kesempatan kali ini, wilayah yang akan dibahas adalah koridor Lingkar Timur Sidoarjo yang tepatnya di Kecamatan Sidoarjo. Aktivitas pembangunan yang terjadi di koridor Lingkar Timur adalah perubahan guna lahan dari lahan hijau menjadi lahan terbangun. Jenis aktivitas yang berkembang pada koridor Lingkar Timur adalah kawasan industri, permukiman, serta perdagangan dan jasa[4].

Pembangunan jalan Lingkar Timur Sidoarjo dapat meningkatkan nilai lokasi dari lahan di sekitar koridor jalan tersebut karena adanya peningkatan aksesibilitas yang ada. Peningkatan nilai lokasi ini kemudian menyebabkan terjadinya alih fungsi lahan dengan kecenderungan kegiatan komersial. Kegiatan komersial merupakan salah satu kegiatan pembangkit pergerakan dimana kegiatan itu merupakan kegiatan yang dilakukan oleh pribadi maupun oleh badan untuk meraup keuntungan (Tamin, 2003). Pemanfaatan lahan pada koridor Lingkar Timur Sidoarjo ditetapkan sebagai kawasan mix use, yang difokuskam pada lahan perdagangan dan industri skala kabupaten (Rencana Tata Ruang Wilayah Kabupaten Sidoarjo Tahun 2009-2029). Jalan Lingkar Timur Sidoarjo juga 
merupakan jalan penghubung antar pusat-pusat kegiatan sehingga mempercepat terjadinya perubahan pembangunan lahan. Perubahan penggunaan lahan yang tidak terkendali menyebabkan perkembangan yang tidak sesuai dengan rencana, hal ini kian menyulitkan dalam mendapatkan rumah yang layak huni dengan harga realistis. Perubahan penggunaan lahan yang terjadi di koridor Lingkar Timur Sidoarjo yang tidak terkendali juga akan mengakibatkan perubahan penggunaan lahan yang tidak sesuai dengan rencana tata ruang wilayah Kabupaten Sidoarjo yang telah diterapkan. Menurut Ketua Asosiasi Pengembang Permukiman dan Permukiman Seluruh Indonesia (Apersi) DPD Jawa Timur Supratno, harga rumah di Sidoarjo melambung hingga dua sampai tiga kali dari nilai jual obyek pajak (NJOP). (Yanuar, 2015)[5].

Perubahan penggunaan lahan yang terjadi di koridor Lingkar Timur Sidoarjo, akan terus menimbulkan dampak yang negatif yaitu terjadinya perubahan penggunaan lahan yang tidak sesuai rencana sehingga perkembangan kawasan tidak berjalan dengan baik. Dengan demikian penentuan kecepatan perubahan penggunaan lahan yang tidak sesuai rencana perlu diketahui untuk dapat mengetahui lahan apa saja yang lebih dibutuhkan oleh penduduk di koridor Lingkar Timur Sidoarjo

\section{METODE PENELITIAN}

\section{A. Metode Pengumpulan Data}

Dalam penelitian ini menggunakan metode pengumpulan data primer dan sekunder. Pengumpulan data dengan survey primer melalui wawancara dan observasi yaitu untuk mengatahui kondisi eksisting pembangunan yang terjadi di koridor.

Data sekunder digunakan sebagai pelengkap data-data primer yang telah didapatkan. Metode pengumpulan data sekunder dalam penelitian ini adalah studi pustaka dan survei instansi. Kebutuhan data tersebut tersedia dalam dokumen rencana serta informasi luas lahan maupun peta yang terjadi per -tahunnya.

\section{B. Metode Analisis}

Metode analisis dalam penelitian ini untuk mengidentifikasi karakteristik kecepatan perubahan penggunaan lahan yang terjadi tidak sesuai rencana menggunakan analisis deskriptif yaitu segmentasi wilayah.

Analisis ini dilakukan untuk mengelompokan percepatan perubahan penggunaan lahan berdasarkan segmen yang telah ditentukan. Analisis ini dilakukan melalui 2 tahap. Tahap pertama dilakukan dengan melakukan perhitungan terhadap luas dan kecepatan perubahan lahan yang merupakan komponen penyusun karakteristik perubahan penggunaan lahan. Perhitungan dilakukan untuk mengetahui luas maupun kecepatan perubahan lahan yang terjadi pada tahun 2006, 2011, dan 2016. Tahap kedua merupakan pengelompokan percepatan harga lahan sesuai dengan karakteristik yang sudah di tentukan. Analisis yang digunakan pada tahap dua ialah analisis deskriptif dengan menggunakan segmentasi wilayah yang sudah ditentukan.

\section{HASIL DAN PEMBAHASAN}

\section{Mengidentifikasi Karakteristik kecepatan perubahan lahan}

Hasil identifikasi karakteristik perubahan penggunaan lahan didapatkan dari analisis perubahan lahan di tahun 2006-2016. Perhitungan penggunaan lahan membutuhkan peta penggunaan lahan pada tahun 2006, 2011, dan 2016 untuk mengetahui variabel yang dibutuhkan yaitu untuk mengetahui luas lahan dan kecepatan perubahan lahan per-5 tahun. Peta rencana koridor Lingkar Timur Sidoarjo juga diperlukan untuk mengetahui ketidak sesuaian perubahan lahan yang terjadi. Kemudian dilakukan perhitungam percepatan menggunakan variabel yang sudah ditentukan.

Pengelompokan dilakukan berdasarkan standar dan peraturan yang sedang berlaku dengan memberikan kategori. Adapun kategori yang diberikan untuk perhitungan yaitu kategori 1 sampai 3. Kategori 1 merupakan percepatan perubahan penggunaan lahan yang terjadi secara cepat, kategori 2 merupakan percepatan perubahan penggunaan lahan yang terjadi secara sedang, dan kategori 3 merupakan percepatan perubahan penggunaan lahan yang terjadi secara lambat. Pada penelitian ini hanya menghitung perubahan penggunaan lahan yang tidak sesuai dengan peta perencana tata ruang. Pada peta tahun 2006, 2011, dan 2016 terjadi terdapat penggunaan lahan yang tidak sesuai dengan rencana kawasan. Berikut merupakan luas lahan yang tidak sesuai rencana di tahun 2006, 2011, dan 2016:

Tabel 1

Luas Lahan yang Tidak Sesuai Rencana Tahun 2006

\begin{tabular}{|c|c|c|c|}
\hline Landuse & $\begin{array}{c}\text { Luas }\left[\mathrm{M}^{2}\right\} \\
\quad(2006)\end{array}$ & $\begin{array}{c}\text { Luas }\left[\mathrm{M}^{2}\right\} \\
\quad(2011)\end{array}$ & $\begin{array}{l}\text { Luas }\left[\mathrm{M}^{2}\right\} \\
\quad(2016)\end{array}$ \\
\hline $\begin{array}{l}\text { Permukiman menjadi } \\
\text { FasilitasUmum }\end{array}$ & 23697.14 & 23697.14 & 23697.14 \\
\hline $\begin{array}{c}\text { Pertanian menjadi } \\
\text { Permukiman }\end{array}$ & 56240.22 & 79521.16 & 94831.46 \\
\hline $\begin{array}{l}\text { Pertanian menjadi } \\
\text { Permukiman }\end{array}$ & 35103.21 & 35103.21 & 35103.21 \\
\hline $\begin{array}{c}\text { Pertanian menjadi } \\
\text { Permukiman }\end{array}$ & 11526.31 & 11526.31 & 24793.34 \\
\hline $\begin{array}{c}\text { Pertanian menjadi } \\
\text { Permukiman }\end{array}$ & 5782.07 & 5782.07 & 11238.21 \\
\hline $\begin{array}{l}\text { Pertanian menjadi } \\
\text { Pergudangan }\end{array}$ & 37187.31 & 73899.24 & 114389.67 \\
\hline $\begin{array}{c}\text { Pertanian menjadi } \\
\text { Pergudangan }\end{array}$ & 17300.1 & 25239.93 & 25239.93 \\
\hline $\begin{array}{c}\text { Permukiman menjadi } \\
\text { fasilitas }\end{array}$ & 10130.26 & 10130.26 & 63770.84 \\
\hline
\end{tabular}

Sumber : Hasil Analiasa 2017

Pada tabel di atas terjadi pertambahan luas lahan yang tidak sesuai rencana di beberapa jenis perubahan yang ada. Pada peta dan tabel luas lahan tahun 2006 hanya menunjukan luas jenis lahan yang tidak sesua dengan rencana. Segmentasi wilayah dibagi menjadi 2 segmen untuk dapat mempermudah mengetahui faktor-faktor perubahan yang terjadi di setiap 
segmen dan di setiap jenis perubahan lahan, berikut merupakan perubahan lahan yang terjadi di masing-masing segmen:

- Segmen 1 adalah Perubahan lahan permukiman menjadi fasilitas umum, pertanian menjadi permukiman, pertanian menjadi pergudangan, dan permukiman menjadi pergudangan.

- Segmen 2 adalah perubahan penggunaan lahan pertanian menjadi fasilitas umum, dan pertanian menjadi permukiman.

Setelah mengetahui kondisi perubahan lahan dalam 10 tahun, dapat diketahui kecepatan perubahan lahan per tahun yang terjadi di koridor Lingkar Timur Sidoarjo dengan disesuaikan dengan kategori yang sudah di tentukan.

$$
\begin{array}{ll}
-\quad 0-2,5 \mathrm{~h} / \mathrm{th} & =\text { Lambat } \\
\text { - } 2,6-5 \mathrm{ha} / \mathrm{th} & =\text { Sedang } \\
\text { - } 5,1-7,5 \mathrm{ha} / \mathrm{th} & =\text { Cepat }
\end{array}
$$

Berikut merupakan kecepatan perubahan lahan yang terjadi di koridor Lingkar Timur Sidoarjo :

\begin{tabular}{|c|c|c|c|c|}
\hline Segmen & Rencana & $\begin{array}{c}\text { Jenis } \\
\text { perubahan } \\
\text { Lahan }\end{array}$ & $\begin{array}{l}\text { Kecepatan } \\
\text { perubahan } \\
\text { lahan ha.th }\end{array}$ & Kategori \\
\hline \multirow[t]{3}{*}{1} & Perjas & $\begin{array}{l}\text { Pertanian } \\
\text { menjadi } \\
\text { permukiman }\end{array}$ & $1,3 \mathrm{ha} / \mathrm{th}$ & Lambat \\
\hline & $\begin{array}{l}\text { Perjas dan } \\
\text { Permukiman }\end{array}$ & $\begin{array}{l}\text { Permukiman } \\
\text { menjadi } \\
\text { Pergudangan }\end{array}$ & 0,7 ha.th & Lambat \\
\hline & $\begin{array}{l}\text { RTH dan } \\
\text { Pertanian }\end{array}$ & $\begin{array}{l}\text { Pertanian } \\
\text { menjadi } \\
\text { Pergudangan }\end{array}$ & $5,9 \mathrm{ha} / \mathrm{th}$ & Cepat \\
\hline \multirow[t]{2}{*}{2} & $\begin{array}{l}\text { Perjas dan } \\
\text { RTH }\end{array}$ & $\begin{array}{l}\text { Pertanian } \\
\text { menjadi } \\
\text { Permukiman }\end{array}$ & $4,4 \mathrm{ha} / \mathrm{th}$ & Sedang \\
\hline & Industri & $\begin{array}{l}\text { Pertanian } \\
\text { menjadi } \\
\text { fasilitas umum }\end{array}$ & $6,3 \mathrm{ha} / \mathrm{th}$ & Cepat \\
\hline
\end{tabular}

Tabel 3. 2

Kecepatan Perubahan Lahan Beserta Kategori

Sumber : hasil analisis 2017

Pada Segmen 1 perubahan lahan pertanian menjadi permukiman tergeolong lambat karena memiliki kecepatan 1,3 ha/th. Pada perubahan lahan ini tidak di haruskan menjadi lahan permukiman melainkan perjas. Perubahan lahan permukiman menjadi pergudangan tergolong kategori lambat karena memiliki kecepatan 0,7 ha/th. Perubahan lahan ini tidak diharuskan menjadi pergudangan melainkan perjas dan permukiman. Perubahan lahan pertanian menjadi pergudangan tergolong cepat karena memiliki kecepatan 5,9 ha/th. Perubahan ;ahan ini tidak di haruskan menjadi lahan pergudangan melainkan RTH dan perjas.

Pada segmen 2 perubahan lahan pertanian menjadi permukiman tergolong sedang karena memiliki kecepatan 4,4 ha/th. Perubahan lahan ini tidak di haruskan menjadi permukiman melainkan perjas dan RTH. Perubahan lahan pertanian menjadi fasilitas umum tergolong kategori cepat karena memiliki kecepatan 6,3 ha/th.perubahan lahan ini tidak diharuskan menjadi fasilitas umum melainkan industri.

\section{KESIMPULAN}

Perubahan lahan yang terjadi tidak sesuai rencana di kawasan Lingkar Timur Sidoarjo dibagi menjadi 2 segmen yang berbeda. Pada segmen satu terdapat 3 jenis perubahan lahan dan pada segmen dua terdapat 2 jenis perubahan lahan yang berbeda dimana masing-masing perubahan lahan memiliki kecepatan perubahan lahan yang berbeda. Pada segmen satu terjadi 3 jenis perubahan lahan yaitu : perubahan lahan pertanian menjadi permukiman dengan kategori lambat yaitu $1,3 \mathrm{ha} / \mathrm{th}$, perubahan lahan permukiman menjadi pergudangan dengan kategori lambat yaitu $0,7 \mathrm{ha} / \mathrm{th}$, dan perubahan lahan pertanian menjadi pergudangan dengan kategori cepat yaitu 5,9ha/th. Pada segmen dua terjadi 2 jenis perubahan lahan yaitu : perubahan lahan pertanian menjadi permukiman dengan kategori sedang yaitu 4,4 ha/th dan perubahan lahan pertanian menjadi fasilitas umum dengan kategori cepat yaitu 6,3 ha/th.

\section{DAFTAR PUSTAKA}

[1] Lisdiono, Khadiyanto. 2004/2006. Pengendalian pemanfaatan ruang di Wilayah Kabupaten Dati II. Bandung : Jurnal PWK ITB, Vol. No. 2.

[2] Sujiarto, Tata Guna Tanah dalam Perencanaan Pedesaan Perkotaan dan Wilayah. Bandung : Institut Teknologi Bandung, 1992.

[3] Nurmadi, Hariyadi. 2014/1994. Pembangunan Perkotaan Berwawasan Lingkungan. Jakarta: Dirjen Cipta Karya Departemen Pekerjaan Umum.

[4] Yunus, Hadi Sabari. 2000. Struktur Tata Ruang Kota. Yogyakarta: Pustaka Pelajar.

[5] Tamin, Yanuar. 2003/2015. Suparno dan Endy Marlina. 2006. Perencanaan dan Pengembangan jalan, nilai lokasi: Sebuah Konsep, Pedoman, dan Strategi Perencanaan dan Pengembangan Permukiman. 